\title{
RYZYKO POWODZIOWE W MIASTACH NADODRZAŃSKICH W KONTEKŚCIE SPOSOBU ZAGOSPODAROWANIA OBSZARÓW ZALEWOWYCH ${ }^{1}$
}

\begin{abstract}
Zarys treści $\quad \mathrm{W}$ pracy podjęto próbę określenia ryzyka powodziowego $\mathrm{w}$ oparciu o sposób zagospodarowania obszarów zalewowych w miastach nadodrzańskich w Polsce. Kryterium oceny ryzyka powodziowego jest powierzchnia zajmowana przez konkretne formy zagospodarowania w granicach terenu zalewowego. Oceny dokonano poprzez uporządkowanie liniowe wszystkich miast nadodrzańskich według poziomu ryzyka powodziowego (ranking miast), a następnie ich pogrupowanie. Otrzymane wyniki odzwierciedlają poziom ryzyka powodziowego miast względem siebie.
\end{abstract}

Słowa kluczowe Ryzyko powodziowe, zagospodarowanie terenu, obszary zalewowe, Odra.

\section{Wprowadzenie}

Współcześnie coraz częściej obserwuje się proces zasiedlania i zagospodarowywania naturalnych obszarów zalewowych. Powoduje to, że powodzie wyrządzają coraz większe straty materialne i niematerialne, zwłaszcza na terenach zurbanizowanych, na których w sposób szczególny nakładają się problemy związane $\mathrm{z}$ ochroną przed powodzią. Wynika to $\mathrm{z}$ charakteru zagospodarowania terenów zalewowych, ich zróżnicowania oraz zróżnicowanej wartości majątku.

W Polsce problematyka oceny poziomu ryzyka powodziowego jest zagadnieniem stosunkowo nowym. Pierwsze badania w tym zakresie prowadzone były w kraju pod koniec lat 90. XX i na początku XXI wieku (Twaróg 1997; Słota 2000; Twaróg 2002, 2004). Problematyka analizy ryzyka powodziowego w Polsce zyskała jednak na znaczeniu dopiero po 2010 roku, kiedy dokonano implementacji

\footnotetext{
${ }^{1}$ Praca została sfinansowana ze środków Narodowego Centrum Nauki przyznanych na podstawie decyzji numer DEC-2011/03/N/HS4/00436.
} 
Dyrektywy Powodziowej do polskiego ustawodawstwa, m.in. do Ustawy Prawo Wodne oraz Ustawy o planowaniu i zagospodarowaniu przestrzennym. Jest zatem aktualna, ma ewidentne walory aplikacyjne, a do tego ma charakter obligatoryjny. Ryzyko powodziowe oznacza kombinację prawdopodobieństwa wystąpienia powodzi i związanych z nią potencjalnych, negatywnych konsekwencji dla zdrowia ludzkiego, środowiska, dziedzictwa kulturowego oraz działalności gospodarczej (Kitowski 2010).

$\mathrm{Na}$ świecie badania w zakresie oceny ryzyka powodziowego są rozwinięte w znacznie większym stopniu. Powszechnie, m.in. w krajach Europy Zachodniej, w tym w Polsce, ryzyko powodziowe określa się na podstawie sporządzonych map ryzyka powodziowego określających: 1) budynki zalane do wysokości do $2 \mathrm{~m}$ i powyżej $2 \mathrm{~m}$ oraz liczbę zagrożonej ludności na terenach powodziowych, 2) formy użytkowania terenu i przypisane im wartości strat powodziowych oraz 3) działalność przemysłową, obszary chronione i inne istotne źródła zanieczyszczeń, np. oczyszczalnie ścieków, cmentarze, elektrociepłownie zlokalizowane na obszarach zalewowych. Mapy ryzyka sporządza się w oparciu o opracowane wcześniej mapy zagrożenia powodziowego, przedstawiające zasięg obszarów zagrożonych powodzią. W Europie Zachodniej w celu obliczenia wysokości potencjalnych szkód stosuje się funkcje bazujące na wycenie poszczególnych obiektów i klas użytkowania (np. w Niemczech - IKSR 2001). Majątek trwały wycenia się na podstawie powodzi historycznych w zależności od klas użytkowania terenu i określa się w euro na $\mathrm{m}^{2}$ poszczególnej klasy użytkowania terenu. W Polsce wartość jednostkową (na ha lub $\mathrm{m}^{2}$ ) określono dla siedmiu form zagospodarowania obszarów zalewowych oraz dodatkowo dla trzech z nich stopień utraty majątku w zależności od głębokości zalewu. Wysokość szkód określa się zatem w zależności od głębokości zalania oraz określonej wcześniej wartości majątku trwałego. Wyznaczone funkcje szkód uzależnione od rodzaju użytkowania terenu przyjmuje się jako procentową utratę wartości w zależności od głębokości zalania. $\mathrm{Na}$ podstawie wartości powierzchni poszczególnych klas użytkowania terenów zalewowych oraz głębokości zalania, korzystając z funkcji strat oraz wartości majątkowych, można określić potencjalne szkody powodziowe (Śliżewski 2008).

Celem badań jest ocena poziomu ryzyka powodziowego wszystkich miast położonych nad Odrą w Polsce na podstawie powierzchni form zagospodarowania terenów zalewowych. Zakres czasowy badań obejmuje lata 1996-2011. Zakres ten podzielono na dwa okresy badawcze: pierwszy (lata 1996-2004) i drugi (2005-2011). W pracy uwagę skupiono na analizie ryzyka powodziowego w ujęciu ekonomicznym, czyli z punktu widzenia potencjalnych strat materialnych mogących powstać w wyniku powodzi. Przeprowadzone analizy nawiązują przede wszystkim do badań nad ekspozycją miast nadodrzańskich na ryzyko powodziowe. 


\section{Obszar i metody badań}

Zakres przestrzenny badań obejmuje wszystkie miasta położone nad rzeką Odrą w Polsce, tj. grupę 20 miast (ryc. 1). Badana grupa jest wewnętrznie silnie zróżnicowana pod względem wielkości (określonej liczbą mieszkańców czy powierzchnią w granicach administracyjnych), jak również rangi administracyjnej i powierzchnią zalewu (terenów zagrożonych powodzią) (tab. 1). Przede wszystkim jednak badane miasta położone są w różnych odcinkach biegu rzeki Odry. Wyróżnić można jej trzy zasadnicze części: 1 - górną Odrę pomiędzy Olzą a ujściem Widawy (przy ujściu Nysy Kłodzkiej dzieli się ją dodatkowo na bieg dolny i górny), 2 - środkową Odrę od ujścia Widawy po ujście Warty oraz 3 -dolną Odrę od ujścia Warty do ujścia Odry do Zalewu Szczecińskiego. Odra w odcinku źródłowym ma górski charakter, przechodząc w niższym biegu w rzekę nizinną.

Największą powodzią w XX wieku w dorzeczu Odry była powódź w lipcu 1997 roku, która wystąpiła w południowo-zachodniej Polsce i którą nazwano powodzią tysiąclecia (DUW 2011). W wyniku tej powodzi najbardziej ucierpiały miasta: Nowa Sól, Krosno Odrzańskie i Bytom Odrzański (w woj. lubuskim), Racibórz (w woj. śląskim), Opole, Kędzierzyn-Koźle, Krapkowice (w woj. opolskim) oraz gmina Oława, miasto Wrocław, gmina Brzeg Dolny (w woj. dolnośląskim) (WBU 2002). Powódź w roku 1997 wykazała, że istniejący system ochrony przeciwpowodziowej w zlewni Odry jest niewystarczający, zwłaszcza zabezpieczenia aglomeracji miejskich położonych nad Odrą (Klepacz, Łagosz 2008; NIK 2011).

Analizowanymi obszarami zalewowymi są obszary bezpośredniego i potencjalnego zagrożenia powodzią o prawdopodobieństwie wystąpienia powodzi $\mathrm{p}=1 \%$, określone na mapach terenów zalewowych przez Regionalne Zarządy Gospodarki Wodnej w Szczecinie, Wrocławiu i Gliwicach odpowiednio w roku 2010, 2003 i dla lat 2003-2006. Obszary bezpośredniego zagrożenia powodzią obejmują tereny między linią brzegu rzeki a linią wałów przeciwpowodziowych lub wysokim naturalnym brzegiem, czyli tzw. obszar międzywala. Tereny potencjalnego zagrożenia powodzią to obszary narażone na zalanie w przypadku przelania się wód przez koronę wałów, zniszczenia lub ich uszkodzenia oraz zniszczenia lub uszkodzenia budowli piętrzących.

Obszar zagrożony powodzią w miastach nadodrzańskich w Polsce wynosi łącznie około 27,6 tys. ha. W górnym biegu Odry znajduje się 10 miast, w środkowym 7, a w dolnym 3. Przeciętny wskaźnik zasięgu zalewu dla ośrodków nadodrzańskich kształtuje się na poziomie $27 \%$ powierzchni miasta. Największym stopniem zagrożenia powodziowego cechują się miasta środkowej Odry - przeciętnie ponad $33 \%$ powierzchni tych miast jest zagrożone powodzią, średnim - miasta górnej Odry (24\%), najniższym - dolnej Odry (23,6\%) (Lechowska 2016). 


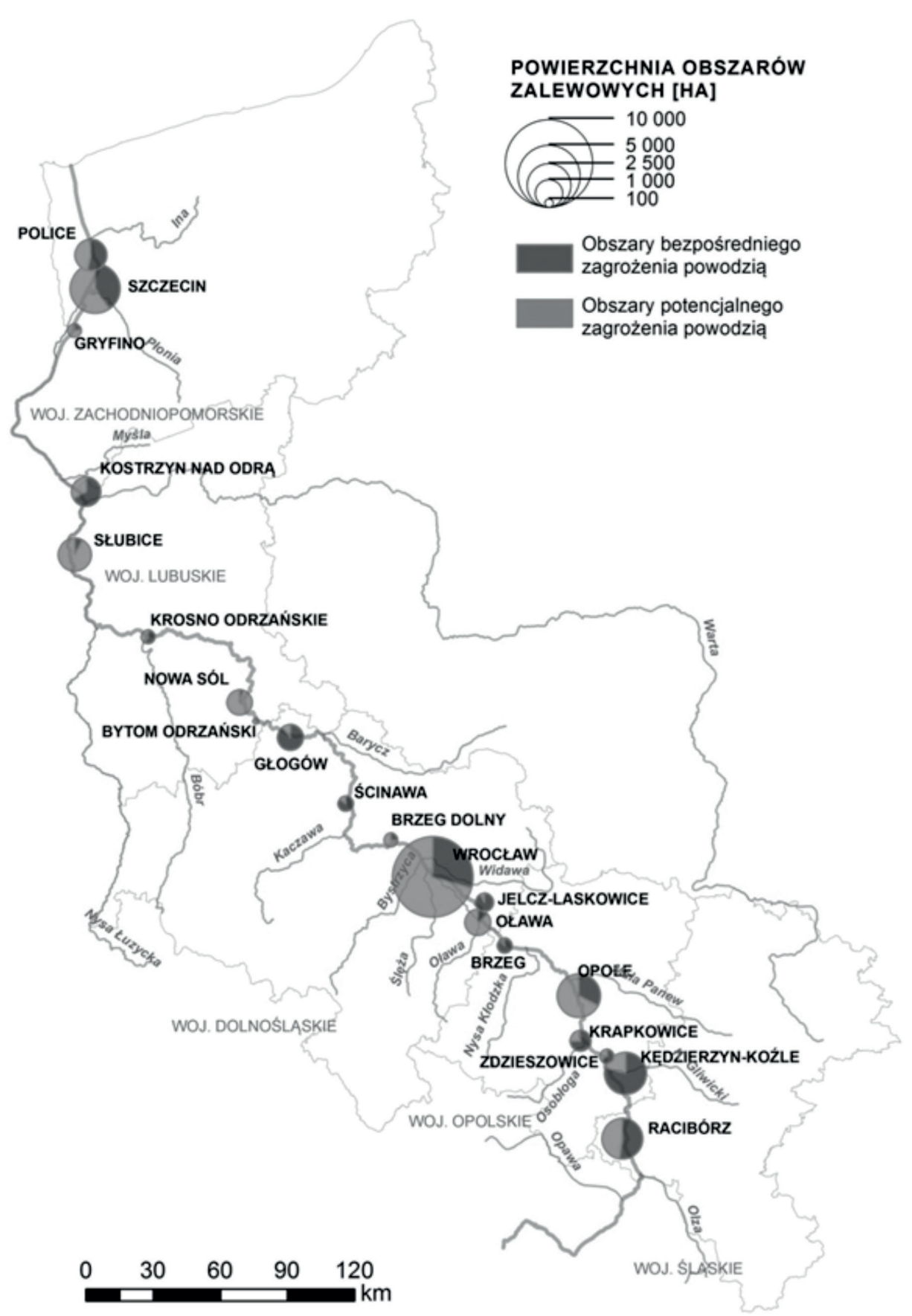

Ryc. 1. Wielkość i struktura terenów zalewowych w miastach nadodrzańskich Źródło: opracowanie własne 
Tabela 1

Charakterystyka społeczno-gospodarcza miast nad Odrą

\begin{tabular}{|c|c|c|c|c|c|c|c|}
\hline Poz & Miasto & $\begin{array}{l}\text { Bieg } \\
\text { rzeki }\end{array}$ & $\begin{array}{l}\text { Pow. } \\
\text { miasta } \\
\left(\text { ha) }{ }^{*}\right.\end{array}$ & $\begin{array}{l}\text { Liczba } \\
\text { ludności } \\
(\mathrm{os})^{*}\end{array}$ & $\begin{array}{c}\text { Ranga } \\
\text { admin. } \\
\text { (siedziba) }\end{array}$ & $\begin{array}{c}\text { Pow. } \\
\text { zalewu } \\
\text { (ha) }\end{array}$ & $\begin{array}{c}\text { Wskaźnik } \\
\text { zalewu } \\
(\%)\end{array}$ \\
\hline 1 & Racibórz & górny & 7498 & 55492 & powiatu & 2146,90 & 28,63 \\
\hline 2 & $\begin{array}{l}\text { Kędzierzyn- } \\
\text {-Koźle }\end{array}$ & górny & 12355 & 62399 & powiatu & 2309,02 & 18,69 \\
\hline 3 & Zdzieszowice & górny & 1233 & 11801 & powiatu & 258,21 & 20,94 \\
\hline 4 & Krapkowice & górny & 2099 & 16789 & powiatu & 555,45 & 26,47 \\
\hline 5 & Opole & górny & 9577 & 118931 & $\begin{array}{c}\text { woje- } \\
\text { wództwa }\end{array}$ & 2448,56 & 25,57 \\
\hline 6 & Brzeg & górny & 1446 & 36469 & powiatu & 247,95 & 19,85 \\
\hline 7 & Oława & górny & 2733 & 32572 & powiatu & 880,05 & 32,20 \\
\hline 8 & $\begin{array}{l}\text { Jelcz- } \\
\text {-Laskowice }\end{array}$ & górny & 1704 & 15853 & powiatu & 423,74 & 24,86 \\
\hline 9 & Wrocław & górny & 29306 & 635759 & $\begin{array}{c}\text { woje- } \\
\text { wództwa }\end{array}$ & 8401,97 & 28,67 \\
\hline 10 & Brzeg Dolny & górny & 1719 & 12420 & gminy & 287,05 & 14,42 \\
\hline 11 & Ścinawa & środkowy & 1353 & 5721 & gminy & 306,03 & 22,61 \\
\hline 12 & Głogów & środkowy & 3498 & 68666 & powiatu & 870,14 & 24,88 \\
\hline 13 & $\begin{array}{l}\text { Bytom } \\
\text { Odrzański }\end{array}$ & środkowy & 230 & 4387 & gminy & 45,39 & 19,77 \\
\hline 14 & Nowa Sól & środkowy & 2180 & 39512 & powiatu & 832,18 & 38,17 \\
\hline 15 & $\begin{array}{l}\text { Krosno } \\
\text { Odrzańskie }\end{array}$ & środkowy & 815 & 11637 & powiatu & 250,60 & 30,75 \\
\hline 16 & Słubice & środkowy & 1923 & 16918 & powiatu & 1410,16 & 73,35 \\
\hline 17 & $\begin{array}{l}\text { Kostrzyn } \\
\text { nad Odrą }\end{array}$ & środkowy & 4618 & 18031 & powiatu & 1121,52 & 24,29 \\
\hline 18 & Gryfino & dolny & 959 & 21450 & powiatu & 241,68 & 25,20 \\
\hline 19 & Szczecin & dolny & 30110 & 405657 & $\begin{array}{c}\text { woje- } \\
\text { wództwa }\end{array}$ & 3207,07 & 10,65 \\
\hline 20 & Police & dolny & 3734 & 33236 & powiatu & 1308,91 & 35,06 \\
\hline
\end{tabular}

* Dane wg GUS na 2015 r.

Źródło: opracowanie własne 
$\mathrm{Na}$ obszarach zalewowych w miastach nadodrzańskich w Polsce dominują obszary potencjalnego zagrożenia powodzią - stanowią one $57 \%$ obszarów zagrożonych tym zjawiskiem. Tereny bezpośrednio zagrożone powodzią obejmują $43 \%$ terenów zalewowych. W nieznacznej większości, tj. w 11 miastach z 20, obszary bezpośredniego zagrożenia powodzią zajmują większą powierzchnię niż tereny potencjalnego zagrożenia. Największą dysproporcję można zauważyć w Krapkowicach, Głogowie, Jelczu-Laskowicach, Kostrzynie nad Odrą, Ścinawie, Zdzieszowicach, Brzegu i Kędzierzynie-Koźlu. Jest to bardzo niebezpieczna sytuacja, ponieważ tereny bezpośredniego zagrożenia, obejmujące z reguły teren międzywala bądź obszar w ogóle niechroniony wałami przeciwpowodziowymi, zostają w pierwszej kolejności zalane wodami powodziowymi w porównaniu do obszarów potencjalnego zagrożenia powodziowego. Z punktu widzenia powierzchni terenów zalewowych, w największym stopniu zagrożone powodzią są duże ośrodki miejskie, położone głównie w górnym biegu rzeki Odry, tj. Wrocław, Opole, Kędzierzyn-Koźle i Racibórz, jak również Szczecin leżący na odcinku dolnej Odry. Bardzo mały obszar zagrożony powodzią występuje w Zdzieszowicach, Krośnie Odrzańskim, Brzegu Dolnym, Gryfinie, a najmniejszy w Bytomiu Odrzańskim (ryc. 1, tab. 1).

Zagospodarowanie terenów zalewowych określono na podstawie ortofotomap i zdjęć lotniczych wykonanych dla obszaru badań w trzech seriach czasowych, tj. w latach 1995-1997, w roku 2004 oraz w latach 2010-2012. Biorąc pod uwagę czas wykonania zobrazowań lotniczych, przyjęto w pracy za okres badań lata 1996-2011, przy czym wyróżniono trzy serie czasowe, tj. rok 1996, 2004 i 2011 i dla nich przeprowadzono analizę ryzyka powodziowego. Identyfikacji form pokrycia i zagospodarowania terenów zalewowych dokonano metodą fotointerpretacji ww. zobrazowań lotniczych metodą klasyfikacji wizualnej za pomocą narzędzi GIS.

Strukturę zagospodarowania terenów zalewowych opisano za pomocą 24 form zagospodarowania terenu (tab. 2). Wyróżnione tereny zabudowy stanowią teren znajdujący się stricte pod budynkiem obejmujący zewnętrzny obrys jego kubatury w przyziemiu, nazywany inaczej powierzchnią jego zabudowy. Za tereny zainwestowane przyjęto tereny zabudowane, zurbanizowane niezabudowane (tereny trawiaste i place) oraz tereny komunikacyjne.

Analizowane obszary zalewowe cechują się zróżnicowanym stopniem zainwestowania. Największe zróżnicowanie udziału terenów zainwestowanych w powierzchni zalewu występuje na obszarach bezpośredniego zagrożenia powodzią (współczynnik zmienności wynosi $73 \%$, podczas gdy na obszarach potencjalnego zagrożenia powodzią - 66\% i terenach zalewowych ogółem - 58\%). Obszary zalewowe ogółem są relatywnie wysoko zainwestowane - grupa miast o wysokim poziomie zainwestowania jest najliczniejsza $\mathrm{z}$ wyróżnionych klas według udziału terenów zainwestowanych $\mathrm{w}$ powierzchni zalewu. Tereny zagrożone powodzią 
Klasyfikacja form pokrycia i zagospodarowania terenów zalewowych

\begin{tabular}{|c|c|c|c|}
\hline Poziom 1 & Poziom2 & Poziom 3 & Poziom 4 \\
\hline \multirow{7}{*}{$\begin{array}{l}\text { Tereny } \\
\text { niezurbanizowane }\end{array}$} & \multirow{2}{*}{ Tereny wód } & \multirow{2}{*}{ Tereny wód } & Tereny wód płynących \\
\hline & & & Tereny wód stojących \\
\hline & \multirow{2}{*}{$\begin{array}{l}\text { Tereny leśne, } \\
\text { zadrzewione } \\
\text { i zakrzewione }\end{array}$} & \multirow{2}{*}{$\begin{array}{l}\text { Tereny leśne, } \\
\text { zadrzewione } \\
\text { i zakrzewione }\end{array}$} & Tereny leśne \\
\hline & & & $\begin{array}{l}\text { Tereny zadrzewione } \\
\text { i roślinności krzewiastej }\end{array}$ \\
\hline & \multirow{3}{*}{ Tereny rolnicze } & \multirow{2}{*}{$\begin{array}{l}\text { Tereny upraw } \\
\text { rolnych }\end{array}$} & Łąki i pastwiska \\
\hline & & & Grunty orne \\
\hline & & $\begin{array}{l}\text { Tereny upraw } \\
\text { trwałych }\end{array}$ & Sady \\
\hline \multirow{17}{*}{$\begin{array}{l}\text { Tereny } \\
\text { zurbanizowane }\end{array}$} & \multirow{4}{*}{$\begin{array}{l}\text { Tereny } \\
\text { semizainwesto- } \\
\text { wane }\end{array}$} & \multirow{4}{*}{$\begin{array}{l}\text { Tereny } \\
\text { rekreacyjne } \\
\text { i wypoczyn- } \\
\text { kowe }\end{array}$} & Zieleń urządzona \\
\hline & & & Cmentarze \\
\hline & & & Ogródki działkowe \\
\hline & & & Place sportowe \\
\hline & \multirow{13}{*}{$\begin{array}{l}\text { Tereny } \\
\text { zainwestowane }\end{array}$} & \multirow{2}{*}{$\begin{array}{l}\text { Tereny } \\
\text { niezabudowane } \\
\text { zurbanizowane }\end{array}$} & Tereny trawiaste \\
\hline & & & $\begin{array}{l}\text { Place utwardzone } \\
\text { i nieutwardzone }\end{array}$ \\
\hline & & \multirow{2}{*}{$\begin{array}{l}\text { Tereny } \\
\text { komunikacyjne }\end{array}$} & Tereny komunikacji kołowej \\
\hline & & & Tereny komunikacji szynowej \\
\hline & & \multirow{9}{*}{$\begin{array}{l}\text { Tereny } \\
\text { zabudowy }\end{array}$} & $\begin{array}{l}\text { Tereny zabudowy } \\
\text { mieszkaniowej }\end{array}$ \\
\hline & & & $\begin{array}{l}\text { Tereny zabudowy } \\
\text { usługowej i handlowej }\end{array}$ \\
\hline & & & Tereny zabudowy biurowej \\
\hline & & & $\begin{array}{l}\text { Tereny zabudowy } \\
\text { usług publicznych }\end{array}$ \\
\hline & & & Tereny zabudowy sakralnej \\
\hline & & & $\begin{array}{l}\text { Tereny zabudowy } \\
\text { przemysłowej i magazynowej }\end{array}$ \\
\hline & & & Tereny zabudowy transportu \\
\hline & & & Tereny zabudowy gospodarczej \\
\hline & & & $\begin{array}{l}\text { Tereny zabudowy } \\
\text { infrastruktury technicznej }\end{array}$ \\
\hline
\end{tabular}

Źródło: opracowanie własne na podstawie Bazy Danych Obiektów Topograficznych i Ewidencji Gruntów i Budynków 
w miastach nadodrzańskich w Polsce są zainwestowane na 19\% swojej ogólnej powierzchni, przy czym tereny chronione wałami przeciwpowodziowymi w większym stopniu aniżeli tereny międzywala (odpowiednio 25\% i 11\%). Najbardziej zainwestowane są tereny zalewowe miast położonych w środkowym odcinku rzeki Odry (przeciętnie w 21\%), w najmniejszym z kolei nad dolną Odrą (11\%), w przeciętnym nad górną Odrą (18\%). W górnym biegu Odry, w porównaniu do pozostałych odcinków rzeki, obszary zagrożone powodzią chronione wałami przeciwpowodziowymi są zainwestowane w największym stopniu (przeciętnie na $29 \%$ obszarów potencjalnego zagrożenia powodzią w tych miastach występują tereny zurbanizowane zabudowane i niezabudowane oraz komunikacyjne, podczas gdy nad środkową Odrą na 26\% i dolną 10\%). Natomiast tereny międzywala w największym stopniu zainwestowane są nad górną Odrą (14\%), w najmniejszym nad górną Odrą (9\%), przeciętnie nad środkową Odrą (12\%).

Ocenę ryzyka powodziowego miast dokonano za pomocą taksonomicznej miary rozwoju zaproponowaną przez Hellwiga. Należy ona do grupy metod wzorcowych, tj. odnoszących się do wyliczonego wzorca rozwoju. Jest to miernik syntetyczny, będący wypadkową wszystkich zmiennych określających cechy badanej zbiorowości. Określa on „odległość” badanego obiektu od teoretycznego wzorca (Starzyk, Walczykiewicz 2000; Feltynowski 2009; Feltynowski, Nowakowska 2009). Zmiennymi opisującymi badany obiekt (miasto) w pracy są powierzchnie zajmowane przez konkretne formy zagospodarowania terenów zalewowych. Przyjęto, że wszystkie wyróżnione formy zagospodarowania terenów mają charakter stymulant, co oznacza, że wzrost ich powierzchni skutkuje wzrostem ryzyka powodziowego. Należy mieć jednak na uwadze, że każdy sposób zagospodarowania wywołuje inne skutki materialne w wyniku wystąpienia powodzi. W związku z tym zmodyfikowano nieznacznie taksonomiczną miarę rozwoju Hellwiga poprzez określenie dla każdej formy zagospodarowania terenu wagi odpowiadającej jednostkowym stratom określonym w polskim ustawodawstwie dotyczącym sporządzania map ryzyka powodziowego ${ }^{2}$ (tab. 3).

${ }^{2}$ Rozporzadzenie Ministra Środowiska, Transportu, Budownictwa i Gospodarki Morskiej, Administracji i Cyfryzacji oraz Spraw Wewnętrznych z dnia 21 grudnia 2012 roku w sprawie opracowania map zagrożenia powodziowego oraz map ryzyka powodziowego (Dz.U., 2013, poz. 104). Dla terenów zabudowy mieszkaniowej, przemysłowo-magazynowej oraz terenów komunikacji przyjęto w pracy uśrednioną wielkość wartości majątku na podstawie określonych w rozporządzeniu wartości majątku w województwach: zachodniopomorskim, lubuskim, dolnośląskim, opolskim i śląskim, na obszarze których zlokalizowane są objęte analizą miasta. W przypadku wyceny terenów trawiastych oraz placów kierowano się cenami rynkowymi. Z kolei z uwagi na brak dostępu do informacji o głębokości zalewu, przyjęto w pracy, że wartości funkcji strat dla terenów zabudowy mieszkaniowej, terenów przemysłowych i komunikacyjnych odpowiadają średnim arytmetycznym wartościom funkcji strat wyznaczonych w ww. rozporządzeniu. 
Wskaźniki jednostkowe strat materialnych (wagi)

\begin{tabular}{|c|c|c|c|}
\hline Formy zagospodarowania terenu & $\begin{array}{l}\text { Wartość } \\
\text { majątku } \\
\left(\mathrm{zl} / \mathrm{m}^{2}\right)\end{array}$ & $\begin{array}{l}\text { Stopień } \\
\text { utraty } \\
\text { majątku } \\
(\%)\end{array}$ & $\begin{array}{c}\text { Waga } \\
\text { - wskaźnik } \\
\text { strat jednost- } \\
\text { kowych } \\
\left(\mathrm{zl} / \mathrm{m}^{2}\right)\end{array}$ \\
\hline Tereny wód płynących & 0,004 & - & 0,004 \\
\hline Tereny wód stojących & 0,004 & - & 0,004 \\
\hline Tereny leśne & 0,008 & - & 0,008 \\
\hline Tereny zadrzewione i roślinności krzewiastej & 0,008 & - & 0,008 \\
\hline Łąki i pastwiska & 0,067 & - & 0,067 \\
\hline Grunty orne & 0,143 & - & 0,143 \\
\hline Sady & 0,286 & - & 0,286 \\
\hline Tereny trawiaste & 1,000 & - & 1,000 \\
\hline Ogródki działkowe & 5,100 & - & 5,100 \\
\hline Zieleń urządzona & 5,100 & - & 5,100 \\
\hline Place utwardzone i nieutwardzone & 7,500 & - & 7,500 \\
\hline Cmentarze & 10,200 & - & 10,200 \\
\hline Place sportowe & 10,200 & - & 10,200 \\
\hline Tereny komunikacji kołowej & 436,000 & 7,5 & 32,700 \\
\hline Tereny komunikacji szynowej & 436,000 & 7,5 & 32,700 \\
\hline Tereny zabudowy transportu & 183,273 & 52,5 & 96,247 \\
\hline Tereny zabudowy gospodarczej & 183,273 & 52,5 & 96,247 \\
\hline Tereny zabudowy mieszkaniowej & 366,654 & 52,5 & 192,493 \\
\hline Tereny zabudowy usługowej i handlowej & 429,626 & 51,0 & 219,396 \\
\hline Tereny zabudowy biurowej & 429,626 & 51,0 & 219,396 \\
\hline Tereny zabudowy usług publicznych & 429,626 & 51,0 & 219,396 \\
\hline Tereny zabudowy sakralnej & 429,626 & 51,0 & 219,396 \\
\hline Tereny zabudowy przemysłowej i magazynowej & 492,598 & 51,0 & 246,299 \\
\hline Tereny zabudowy infrastruktury technicznej & 615,748 & 51,0 & 307,874 \\
\hline
\end{tabular}

Źródło: opracowanie własne na podstawie Rozporządzenia... (2012). 
Finalnie, wykorzystana miara taksonomiczna pozwala na uporządkowanie badanych miast w zależności od odległości od wzorca rozwoju, w niniejszej pracy oznacza to uporządkowanie liniowe miast według malejącego poziomu ryzyka powodziowego, a następnie ich pogrupowanie. Podziału dokonano przy dużych skokach jednostkowych w uporządkowanym szeregu miary syntetycznej. Wydzielono pięć klas o poziomie ryzyka od bardzo niskiego do bardzo wysokiego. Granice klas wyznaczono metodą punktów charakterystycznych, tj. w miejscach załamania się ciągłości zbioru obserwacji.

\section{Wyniki}

Wyniki analizy przedstawiają poziom ryzyka powodziowego miast względem siebie i poprzez analizę otrzymanych rankingów pozwalają porównać potencjalne całkowite straty powodziowe $\mathrm{w}$ grupie badanych miast w ujęciu statycznym i dynamicznym.

\subsection{Poziom ryzyka powodziowego}

Analizę poziomu ryzyka powodziowego w miastach nadodrzańskich przeprowadzono dla najbardziej aktualnego, ostatniego roku analizowanego okresu, tj. dla 2011 roku, dla terenów zalewowych ogółem oraz odrębnie dla obszarów bezpośredniego i potencjalnego zagrożenia powodzią.

Analizując obszary zalewowe ogółem, w grupie badanych miast większość ośrodków charakteryzuje się co najwyżej średnim poziomem ryzyka powodziowego (12 na 20 miast) (ryc. 2). Wysokie i bardzo wysokie całkowite straty powodziowe mogą wystąpić w 8 miastach na 20 badanych. Bardzo wysokie ryzyko powodziowe odnotowano we Wrocławiu, co wynika z bardzo dużej powierzchni obszarów zagrożonych powodzią. Wysokie potencjalne straty powodziowe w Opolu, Raciborzu i Kędzierzynie-Koźlu są efektem zarówno dużych pod względem powierzchni terenów zalewowych, jak i wysokiego zainwestowania tych obszarów, w Słubicach i Nowej Soli - z dużego udziału terenów zainwestowanych, a w Szczecinie - dużej powierzchni obszarów zagrożonych powodzią. Miasta o średnim poziomie strat powodziowych charakteryzują się niską i średnią wielkością obszarów zalewowych przy zróżnicowanym stopniu ich zainwestowania (od niskiego do wysokiego) (tj. Brzeg Dolny, Krapkowice, Police, Oława, Brzeg, Krosno Odrzańskie, Głogów). Na niski poziom ryzyka powodziowego w Jelczu-Laskowicach, Bytomiu Odrzańskim i Gryfinie większy wpływ ma wielkość terenów zagrożonych powodzią (niska i bardzo niska) niż sposób ich zagospodarowania (średni lub bardzo wysoki stopień zainwestowania). $Z$ kolei w ośrodkach o bardzo niskim ryzyku powodziowym, wysokość potencjalnych strat wynika przede wszystkim z poziomu zainwestowania obszarów zagrożo- 
nych powodzią. Są to bowiem głównie miasta cechujące się niższym udziałem terenów zainwestowanych (bardzo niski) w porównaniu do ich wielkości (mała), tj. Ścinawa i Zdzieszowice (ryc. 2).

Z powyższych obserwacji można wnioskować, że poziom ryzyka powodziowego w miastach nadodrzańskich zależy w pewnym stopniu od wielkości terenów zalewowych. Przeprowadzona analiza korelacji wskazuje na taką zależność $(r=0,42$ przy $p \leq 0,05)$. Nie zaobserwowano natomiast istotnie statystycznej korelacji między wysokością potencjalnych strat powodziowych a sposobem zagospodarowania (stopniem zainwestowania) obszarów zagrożonych powodzią. Jak wynika z powyższych obserwacji, udział terenów zainwestowanych ma znaczenie jedynie w przypadku wysokiego i bardzo niskiego poziomu ryzyka powodziowego.

Analizując pierwszą strefę zalewową, więcej miast niż w przypadku analiz dotyczących terenów zalewowych ogółem, wykazuje relatywnie niski i bardzo niski poziom ryzyka powodziowego (8 a 5 ośrodków) (ryc. 2,3). Na bardzo wysokie potencjalne straty mogące powstać $\mathrm{w}$ wyniku powodzi na terenach międzywala w Kędzierzynie-Koźlu ma większy wpływ sposób zagospodarowania (zainwestowania) tych terenów (bardzo wysoki) niż ich powierzchnia (duża). Wśród miast o wysokim poziomie ryzyka powodziowego na terenach bezpośredniego zagrożenia powodzią we Wrocławiu, wysokość potencjalnych strat powodziowych wynika z wielkości tych terenów (bardzo duża), z kolei w Brzegu - z bardzo wysokiego stopnia ich zainwestowania. W pozostałych ośrodkach (Kostrzynie nad Odrą i Szczecinie) wysokie straty mogące powstać w wyniku powodzi w pierwszej strefie zalewowej są związane zarówno ze sposobem zagospodarowania tych obszarów, jak i ich wielkością. Miasta, w których na obszarach bezpośredniego zagrożenia powodzią określono średni poziom ryzyka powodziowego, ich pierwsza strefa zalewowa $\mathrm{z}$ reguły zainwestowana jest $\mathrm{w}$ niskim stopniu i zajmuje przeciętną, w stosunku do pozostałych ośrodków nadodrzańskich, powierzchnię (Police, Racibórz, Głogów, Opole, Krapkowice). Jedynie w Krośnie Odrzańskim średni poziom ryzyka powodziowego na obszarach bezpośredniego zagrożenia powodzią wynika z wysokiego stopnia zainwestowania tych terenów przy stosunkowo małej ich powierzchni. Niskie ryzyko powodziowe w pierwszej strefie w badanej grupie miast nadodrzańskim wynika raczej z wielkości obszarów bezpośredniego zagrożenia powodzią (bardzo mała w 4 miastach, mała w 3 miastach) aniżeli ze sposobu ich zagospodarowania (niski stopień zainwestowania w 4 miastach, średni w 1 mieście, wysoki w 2 miastach). Bardzo niskie ryzyko powodziowe w Słubicach na obszarach międzywala związane jest w większym stopniu z ich sposobem zainwestowania (bardzo niski) niż z ich wielkością (stosunkowo mała powierzchnia) (ryc. 3).

$\mathrm{Z}$ powyższego można wnioskować, że poziom ryzyka powodziowego na obszarach bezpośredniego zagrożenia powodzią jest związany zarówno z wielkością tych obszarów, jak i sposobem ich zagospodarowania wyrażonym stopniem 


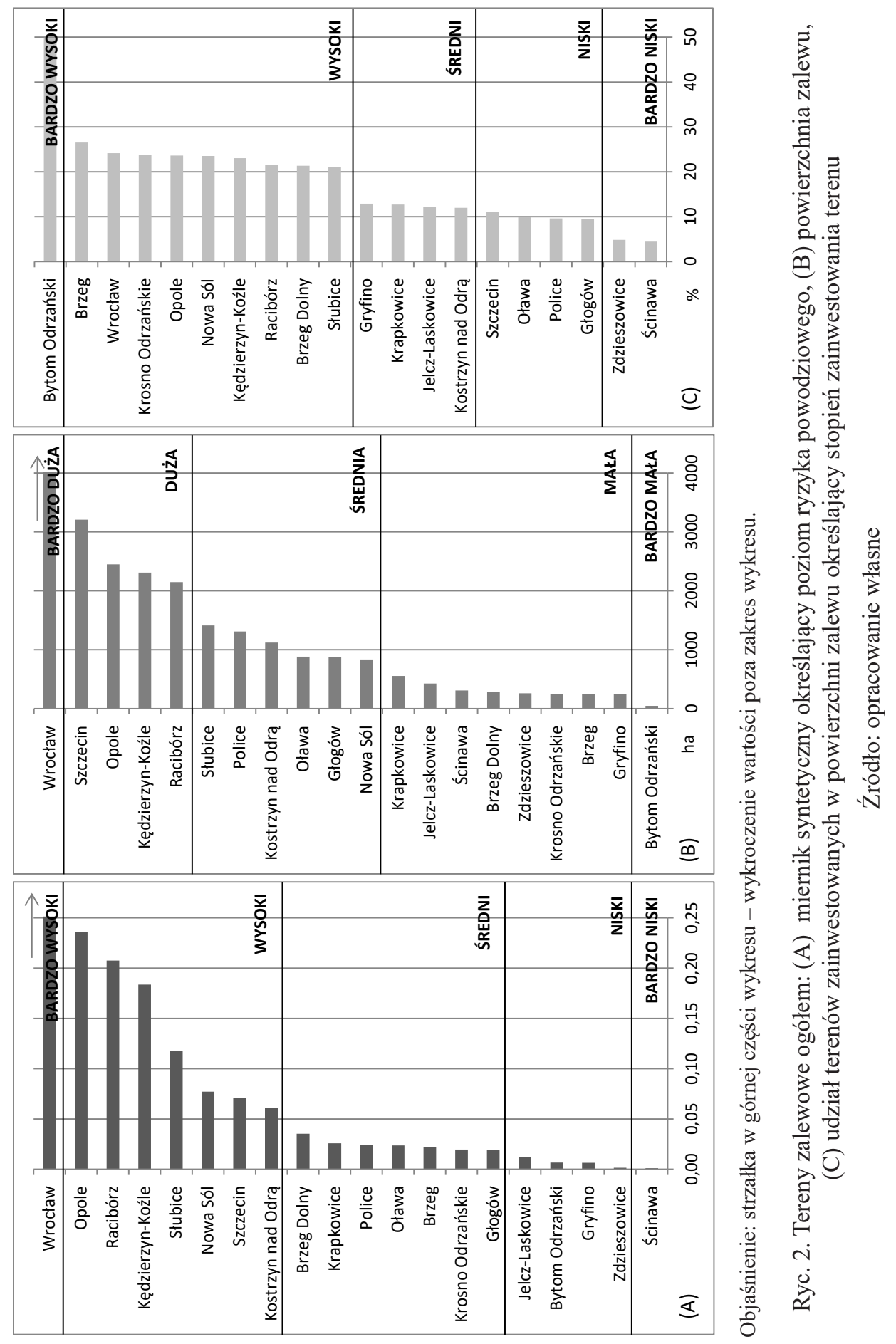




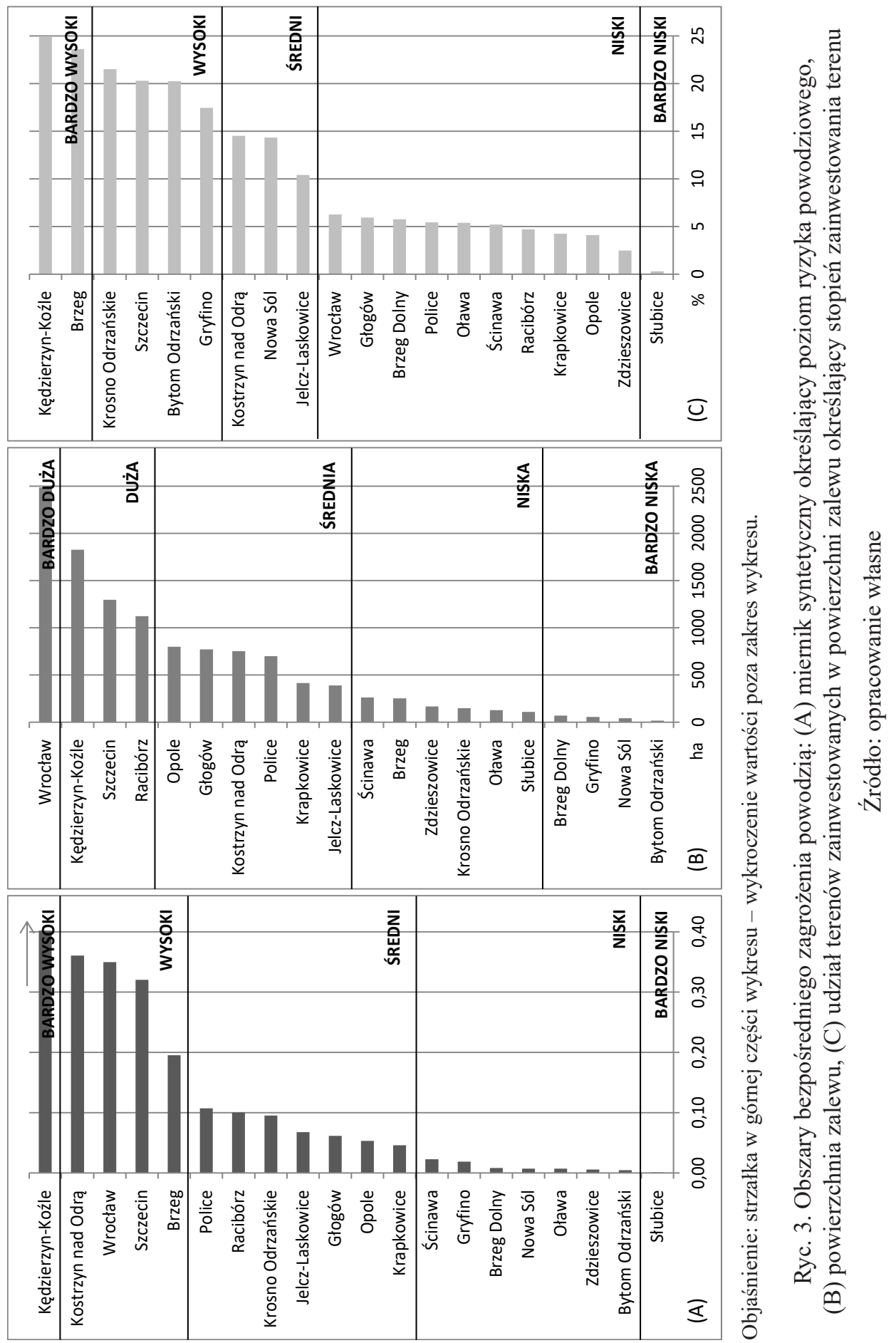


zainwestowania. Przeprowadzona analiza korelacji potwierdza te zależności (współczynniki korelacji wynoszą odpowiednio 0,70 i 0,51 przy p $\leq 0,05$ ) i wskazuje, że w przypadku pierwszej strefy zalewowej powierzchnia terenów zagrożonych powodzią bardziej wpływa na poziom ryzyka niż poziom ich zainwestowania. Nie dotyczy to jednak bardzo wysokiego i bardzo niskiego poziomu ryzyka powodziowego, który w niniejszych badaniach wynika przede wszystkim odpowiednio z bardzo wysokiego lub bardzo niskiego udziału terenów zainwestowanych w powierzchni obszarów bezpośredniego zagrożenia powodzią.

Analizując ryzyko powodziowe w drugiej strefie zalewowej (na obszarach potencjalnego zagrożenia powodzią), lista rankingowa badanych miast prezentuje się odmiennie od tej właściwej dla pierwszej strefy, o czym świadczy m.in. obliczony współczynnik korelacji między miernikami syntetycznymi określającymi poziom ryzyka powodziowego dla pierwszej i drugiej strefy zalewowej nieistotny statystycznie (tab. 4). W porównaniu do pierwszej strefy zalewowej, w drugiej większa liczba miast cechuje się niskim ryzykiem powodziowym względem pozostałych badanych ośrodków nadodrzańskich (9 a 7 miast) (ryc. 3, 4). Bardzo wysokie potencjalne straty powodziowe odnotowane we Wrocławiu na obszarach potencjalnego zagrożenia powodzią wynikają przede wszystkim z bardzo dużej powierzchni tej strefy zalewowej w tym mieście, która jest zainwestowana w średnim stopniu. Na wysoki poziom ryzyka powodziowego na obszarach potencjalnego zagrożenia powodzią w badanych miastach nadodrzańskich ma wpływ przede wszystkim wielkość tych terenów (duża powierzchnia), w mniejszym zaś sposób ich zagospodarowania (średni stopień zainwestowania) (Opole, Słubice). Wśród miast o wysokim poziomie ryzyka powodziowego, jedynie Racibórz cechuje się zarówno wysokim udziałem terenów zainwestowanych, jak i relatywnie dużą powierzchnią obszarów potencjalnego zagrożenia powodzią. Miasta o stosunkowo przeciętnym poziomie ryzyka powodziowego $\mathrm{w}$ analizowanej strefie zalewowej cechują się z reguły średnią lub niską powierzchnią tych obszarów zalewowych i niskim stopniem ich zainwestowania (Oława i Kędzierzyn-Koźle, przy czym Szczecin odznacza się dużą powierzchnią, Brzeg Dolny - średnim, a Krapkowice - wysokim stopniem zainwestowania obszarów potencjalnego zagrożenia powodzią). Miasta o niskim ryzyku powodziowym w drugiej strefie zalewowej cechują się zazwyczaj niską bądź bardzo niską powierzchnią tej strefy zalewowej przy zróżnicowanym stopniu zainwestowania tych terenów (od niskiego do bardzo wysokiego) (tj. Głogów, Police, Bytom Odrzański, Krosno Odrzańskie, Brzeg, Gryfino, Kostrzyn nad Odrą, Jelcz-Laskowice, Zdzieszowice). W Ścinawie bardzo niskie ryzyko powodziowe w drugiej strefie zalewowej związane jest z bardzo małą powierzchnią obszarów analizowanej strefy zalewowej oraz bardzo niskim jej zainwestowaniem (ryc. 4).

Biorąc powyższe czynniki pod uwagę można stwierdzić, że poziom ryzyka powodziowego określony dla obszarów potencjalnego zagrożenia powodzią 


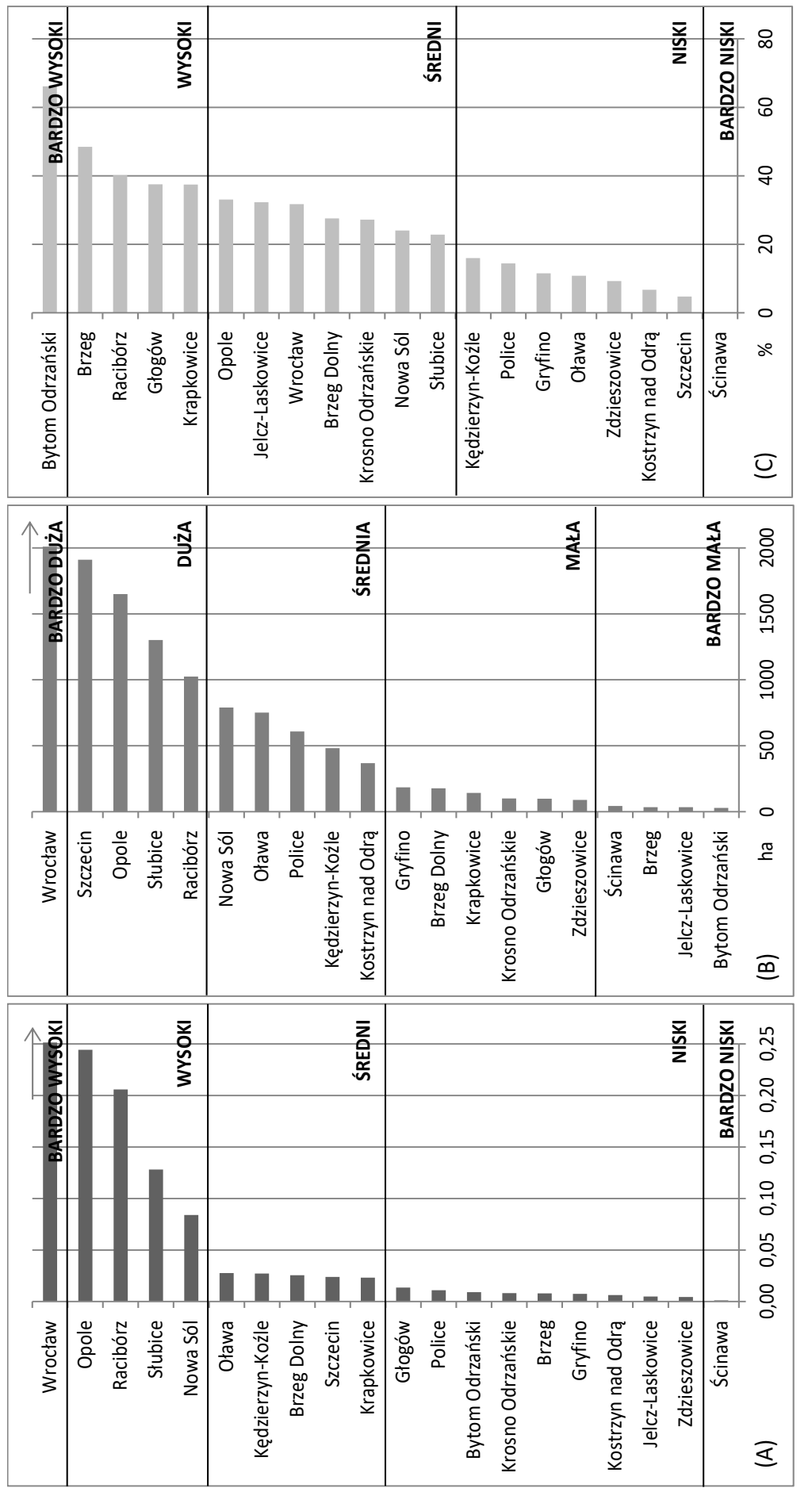

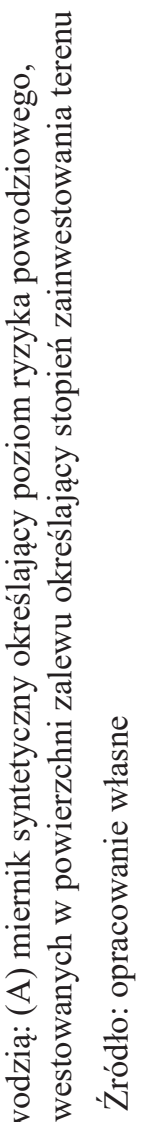

ฉ.

월

. ํ.

$\overrightarrow{5} \quad 50$

羟

\$ 800

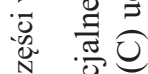

ब.

品

3 矛.

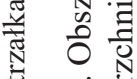

के $\dot{0} \cdot \overrightarrow{0}$

苛这

กิ 
zależy w dużej mierze od powierzchni obszarów zagrożonych powodzią. Potwierdza to przeprowadzona analiza korelacji - współczynnik korelacji wynosi 0,95 przy $\mathrm{p} \leq 0,05$. Zainwestowanie terenów zalewowych ma wpływ na wysokość potencjalnych strat powodziowych jedynie w przypadku ich bardzo niskiego poziomu. W pozostałych przypadkach na poziom ryzyka powodziowego (od niskiego do bardzo wysokiego) w niniejszych badaniach wpływ ma wielkość terenów zalewowych.

Poziom ryzyka powodziowego na terenach zalewowych ogółem wynika przede wszystkim z wysokości potencjalnych strat powodziowych określonych dla drugiej strefy zalewowej, o czym świadczy obliczony wskaźnik korelacji wynoszący 0,99 (tab. 4). Może być to związane z tym, że obszary potencjalnego zagrożenia powodzią przeważają pod względem powierzchni na badanych terenach zalewowych. Analiza korelacji nie wykazała istotnej statystycznie zależności poziomu ryzyka powodziowego od stopnia zainwestowania terenów zalewowych chronionych wałami przeciwpowodziowymi $(\mathrm{r}=0,16$ przy $\mathrm{p} \leq 0,05)$.

Tabela 4

Macierz korelacji między poziomem ryzyka powodziowego terenów zalewowych ogółem a poszczególnymi strefami zalewowymi

\begin{tabular}{lccc}
\hline \multicolumn{1}{c}{ Wyszczególnienie } & $\begin{array}{c}\text { Obszary } \\
\text { bezpośredniego } \\
\text { zagrożenia } \\
\text { powodzią }\end{array}$ & $\begin{array}{c}\text { Obszary } \\
\text { potencjalnego } \\
\text { zagrożenia } \\
\text { powodzią }\end{array}$ & $\begin{array}{c}\text { Obszary } \\
\text { zalewowe ogółem }\end{array}$ \\
\hline $\begin{array}{l}\text { Obszary bezpośredniego } \\
\text { zagrożenia powodzią }\end{array}$ & 1,00 & - & - \\
\hline $\begin{array}{l}\text { Obszary potencjalnego } \\
\text { zagrożenia powodzią }\end{array}$ & $0,16^{* *}$ & 1,00 & - \\
\hline $\begin{array}{l}\text { Obszary zalewowe } \\
\text { ogółem }\end{array}$ & $0,33^{* *}$ & $0,99^{*}$ & 1,00 \\
\hline
\end{tabular}

$*$ istotne statystycznie przy $\mathrm{p} \leq 0,05$.

** nieistotne statystycznie przy $\mathrm{p} \leq 0,05$.

Źródło: opracowanie własne

Bezpośrednie porównywanie ryzyka powodziowego między strefami zalewowymi jest w niniejszej pracy niemożliwe, ponieważ określone na potrzeby artykułu ryzyko powodziowe przedstawia poziom potencjalnych strat powodziowych w miastach względem siebie w układzie hierarchicznym (ranking).

Otrzymane wyniki nie wskazują ponadto na zależność poziomu ryzyka powodziowego od położenia miasta w biegu rzeki. Tyczy się to zarówno obszarów zalewowych ogółem, jak i poszczególnych stref zalewowych, co potwierdzają 
obliczone współczynniki korelacji nieistotne statystycznie (dla terenów zalewowych ogółem $r=-0,18$, obszarów bezpośredniego zagrożenia powodzią $r=-0,19$, obszarów potencjalnego zagrożenia powodzią $\mathrm{r}=-0,15$, przy $\mathrm{p} \leq 0,05)$.

\subsection{Zmiany ryzyka powodziowego}

Zmiany poziomu ryzyka powodziowego określono poprzez porównanie pozycji miast $\mathrm{w}$ rankingach określających uporządkowanie liniowe miast według malejącego poziomu ryzyka powodziowego dla 1996, 2004 i 2011 roku. Analizę wykonano dla terenów zalewowych ogółem oraz odrębnie dla pierwszej i drugiej strefy zalewowej.

W latach 1996-2011 na obszarach zalewowych ogółem w 9 miastach z 20, zaobserwowano zmianę poziomu ryzyka powodziowego względem pozostałych, badanych ośrodków miejskich (ryc. 5). Polegały one przede wszystkim na spadku lokaty w rankingu (w pięciu miastach o jedną bądź dwie pozycje), czyli spadku ryzyka powodziowego w tych miastach względem pozostałych ośrodków (tj. w Szczecinie, Brzegu, Policach, Brzegu Dolnym i Głogowie). Wzrost poziomu ryzyka powodziowego nastąpił z kolei w mniejszej liczbie miast (czterech), ale osiągnął większą rozpiętość (od jednej do trzech pozycji) (tj. w Nowej Soli, Kostrzynie nad Odrą, Krapkowicach i Oławie). Zarówno spadki, jak i wzrosty poziomu ryzyka powodziowego względem innych miast odnotowano w ośrodkach plasujących się w środkowej części hierarchii, czyli przeważnie w miastach o średnim i niskim poziomie ryzyka powodziowego (średni - 4 miasta, niski - 3 miasta, bardzo niski - 1 miasto, wysoki - 1 miasto) (ryc. 5). Zaobserwowany spadek ryzyka powodziowego względem pozostałych ośrodków wynika głównie ze spadku ryzyka w drugiej części analizowanego okresu (tj. w latach 2005-2011), natomiast wzrost - ze wzrostów odnotowanych w pierwszej części analizowanego okresu (tj. w latach 1996-2004).

Rozpatrując poszczególne okresy analizy, na obszarach zalewowych ogółem przed 2004 rokiem w miastach nadodrzańskich nastąpiły przede wszystkim spadki pozycji w rankingu, które świadczą o obniżeniu ryzyka powodziowego w określonych miastach względem pozostałych (tj. w Krośnie Odrzańskim, Brzegu Dolnym, Głogowie i Policach) (ryc. 6). Natomiast po 2004 roku zaobserwowano taką samą liczbę spadków, jak i wzrostów lokat w badanych miastach. W pięciu miastach doszło do spadku pozycji w rankingu lub jej zachowania w pierwszej bądź drugiej części badanego okresu (w Brzegu Dolnym, Głogowie, Policach, Brzegu i Szczecinie), natomiast do wzrostu zarówno w pierwszej, jak i drugiej części - doszło jedynie w dwóch miastach (tj. w Kostrzynie nad Odrą i Krapkowicach). „Spowolnienie” ryzyka powodziowego zaobserwowano jedynie w Oławie, gdzie doszło na początku do bardzo wysokiego wzrostu pozycji w rankingu, a następnie zachowaniu lokaty po 2004 roku. „Pobudzenie” ryzyka 


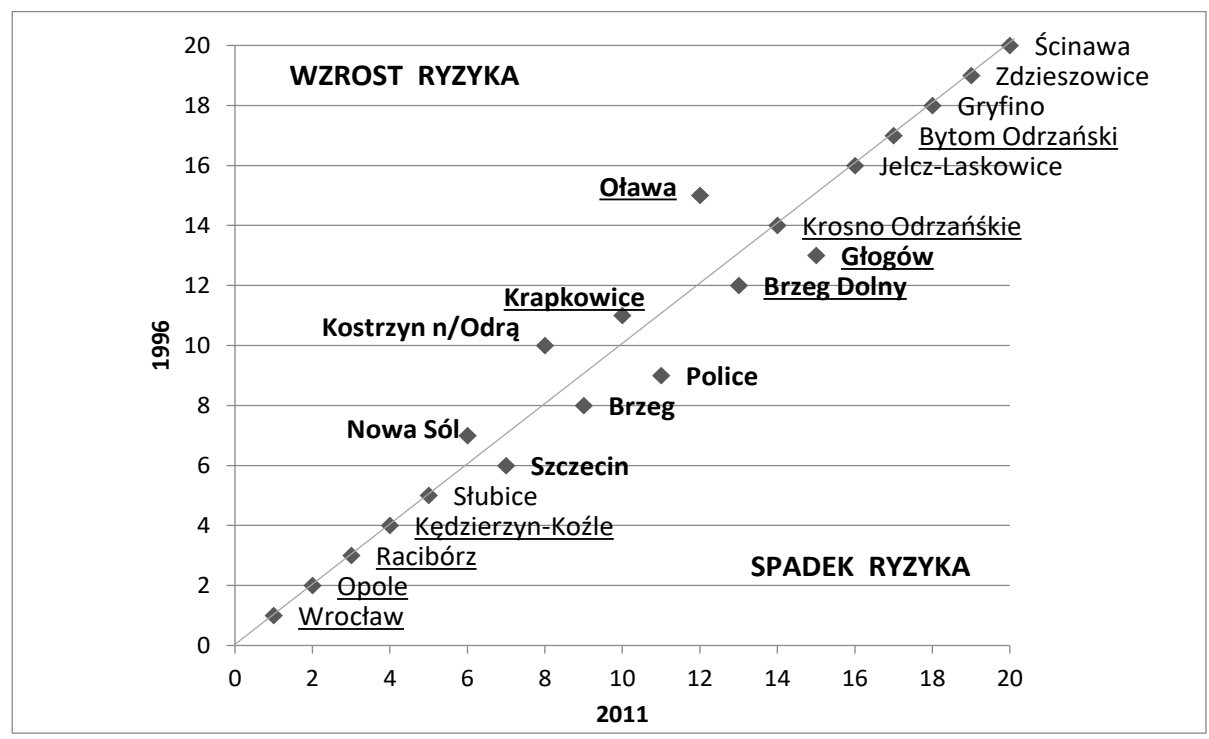

Podkreślenie - miasta dotknięte powodzią w $1997 \mathrm{r}$.

Wytłuszczenie - miasta, których pozycja w rankingu uległa zmianie.

Ryc. 5. Ranking miast według malejącego poziomu ryzyka powodziowego na terenach zalewowych ogółem w latach 1996-2011 - zmiany pozycji

\section{Źródło: opracowanie własne}

powodziowego odnotowano w dwóch miastach (Krośnie Odrzańskim i Nowej Soli), w których w pierwszej części analizowanego okresu nastąpił spadek lokaty lub jej zachowanie, a następnie wzrost. Aż w dziesięciu miastach zarówno przed, jak i po 2004 roku nie odnotowano zmiany pozycji w rankingu (tj. w Gryfinie, Słubicach, Bytomiu Odrzańskim, Ścinawie, Wrocławiu, Jelczu-Laskowicach, Opolu, Raciborzu i Kędzierzynie-Koźlu) (ryc. 6).

W pierwszej strefie zalewowej zmiany pozycji dotyczyły głównie spadku lokaty miasta w hierarchii, co oznacza spadek poziomu ryzyka powodziowego w tych ośrodkach (sześciu) względem pozostałych (tj. we Wrocławiu, Szczecinie, Brzegu, Krośnie Odrzańskim, Opolu i Głogowie) (ryc. 7). Z kolei jedynie $\mathrm{w}$ trzech miastach nastąpił wzrost ryzyka powodziowego w stosunku do pozostałych ośrodków (tj. w Kostrzynie nad Odrą, Raciborzu i Jelczu-Laskowicach). Wzrosty te były bardziej dynamiczne niż odnotowane spadki pozycji (w pierwszym przypadku z reguły o trzy pozycje, w drugim - o jedną) (ryc. 7). Zmiany ryzyka powodziowego względem innych miast w ramach tej strefy tyczą się przede wszystkim ośrodków o wysokim i średnim poziomie ryzyka powodziowego i wynikają ze zmian lokat w drugiej części analizowanego okresu, tj. po 2004 roku. 


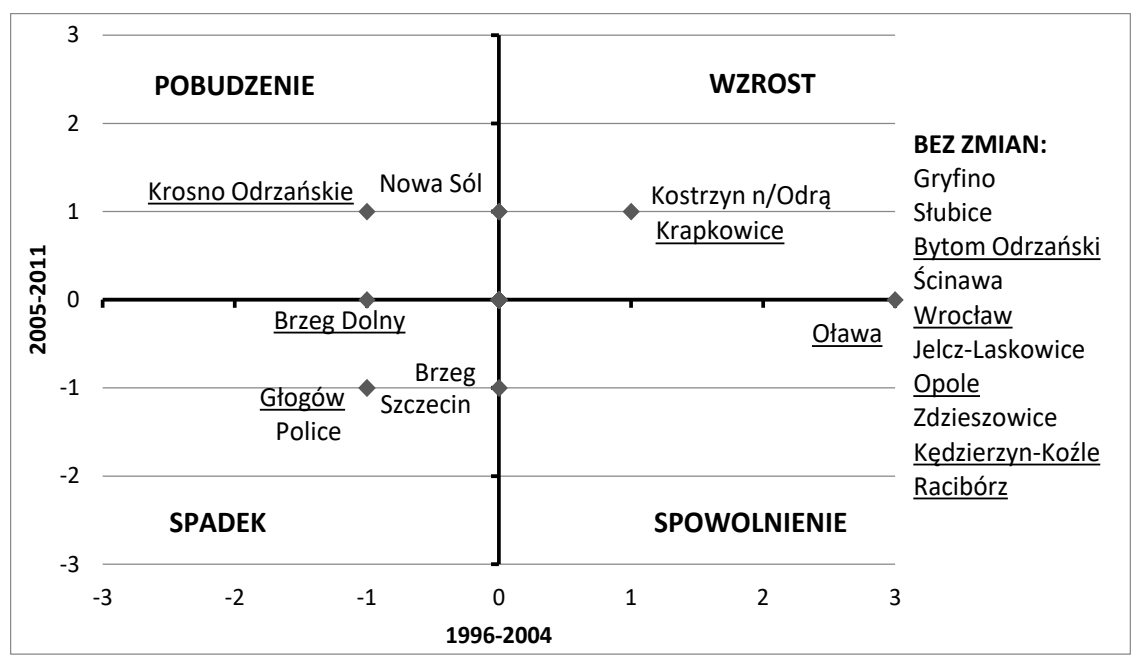

Podkreślenie - miasta dotknięte powodzią w $1997 \mathrm{r}$.

Ryc. 6. Zmiana pozycji w rankingu według malejącego poziomu ryzyka powodziowego na terenach zalewowych ogółem w latach 1996-2004 i 2005-2011 Źródło: opracowanie własne

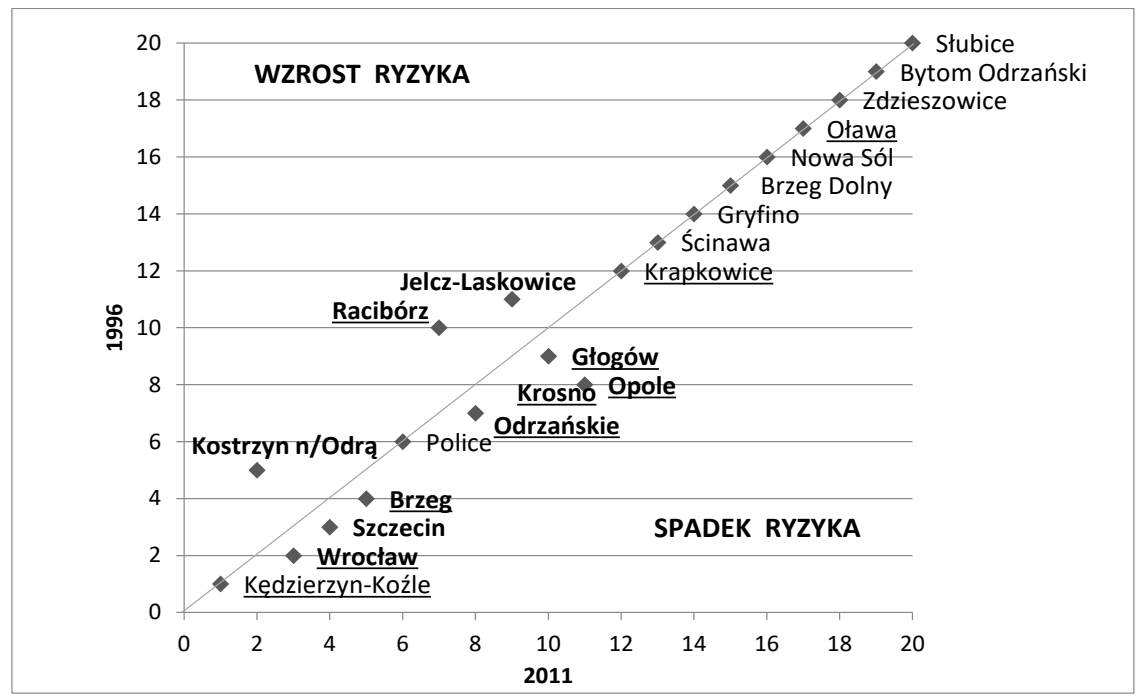

Podkreślenie - miasta dotknięte powodzią w $1997 \mathrm{r}$.

Wytłuszczenie - miasta, których pozycja w rankingu uległa zmianie.

Ryc. 7. Ranking miast według malejącego poziomu ryzyka powodziowego na obszarach bezpośredniego zagrożenia powodzią w latach 1996-2011

$$
\text { - zmiany pozycji }
$$

Źródło: opracowanie własne 
W pierwszej strefie zalewowej bowiem druga część badanego okresu cechuje się większą liczbą zmian (głównie spadki) pozycji miast na liście rankingowej (tj. w Szczecinie, Krośnie Odrzańskim, Głogowie, Wrocławiu, Oławie i Jelczu-Laskowicach) (ryc. 8). W pierwszej części z kolei, tj. w latach 1996-2004, zmiany lokat miast w hierarchii są bardziej dynamiczne (z reguły mają większą rozpiętość) i dotyczą w takim samym stopniu zarówno spadków (w Nowej Soli, Brzegu Dolnym i Opolu), jak i wzrostów pozycji (w Kostrzynie nad Odrą, Oławie i Jelczu-Laskowicach). Oprócz grupy miast, w przypadku których nie doszło do zmiany pozycji na liście rankingowej według malejącego poziomu ryzyka powodziowego (dziewięć ośrodków: Police Gryfino, Słubice, Bytom Odrzański, Ścinawa, Brzeg, Krapkowice, Zdzieszowice, Kędzierzyn-Koźle), liczną grupę stanowią też miasta, w których odnotowano spadek pozycji w rankingu lub jej zachowanie w pierwszej bądź drugiej części badanego okresu (sześć miast: Opole, Brzeg Dolny, Szczecin, Krosno Odrzańskie, Głogów, Wrocław). Natomiast jedynie w Kostrzynie nad Odrą zaobserwowano wzrost ryzyka powodziowego względem innych ośrodków zarówno w pierwszej, jak i drugiej części analizowanego okresu. „Pobudzenie” ryzyka powodziowego nastąpiło w dwóch miastach (w Raciborzu i Nowej Soli), podobnie jak jego „spowolnienie” (w Oławie i Jelczu-Laskowicach) (ryc. 8).

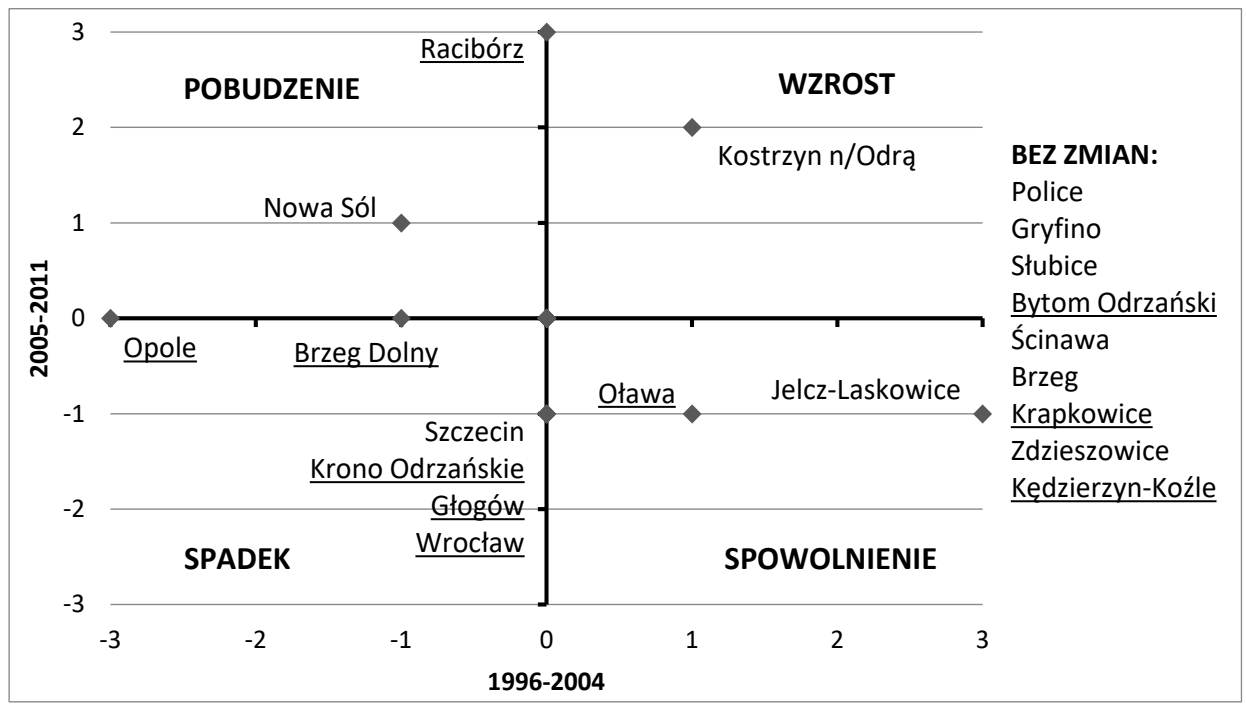

Podkreślenie - miasta dotknięte powodzią w 1997 r.

Ryc. 8. Zmiana pozycji w rankingu według malejącego poziomu ryzyka powodziowego na obszarach bezpośredniego zagrożenia powodzią w latach 1996-2004 i 2005-2011 Źródło: opracowanie własne

Podobnie, jak w pierwszej strefie zalewowej, w drugiej strefie zmiany lokat w rankingu polegały głównie na spadku pozycji poszczególnych ośrodków względem pozostałych, czyli spadku ryzyka powodziowego w tych miastach względem 
drugich (tj. w Brzegu Dolnym, Szczecinie, Krapkowicach, Policach, Brzegu, Kostrzynie nad Odrą i Zdzieszowicach) (ryc. 9). Zarówno spadki, jak i wzrosty lokat dotyczyły z reguły zmiany pozycji o jedną lokatę. Większe rozpiętości zmian odnoszą się do jednostkowych przypadków (w Oławie wzrost o cztery pozycje, w Brzegu spadek o dwie lokaty). Zmiany poziomu ryzyka powodziowego w grupie badanych miast względem siebie odnotowano przede wszystkim w ośrodkach o niskim i bardzo niskim ryzyku powodziowym (ryc. 9). Zaobserwowane spadki, jak i wzrosty w tej strefie zalewowej wynikają przede wszystkim ze zmian poziomu ryzyka w pierwszej części badanego okresu (tj. w latach 1996-2004).

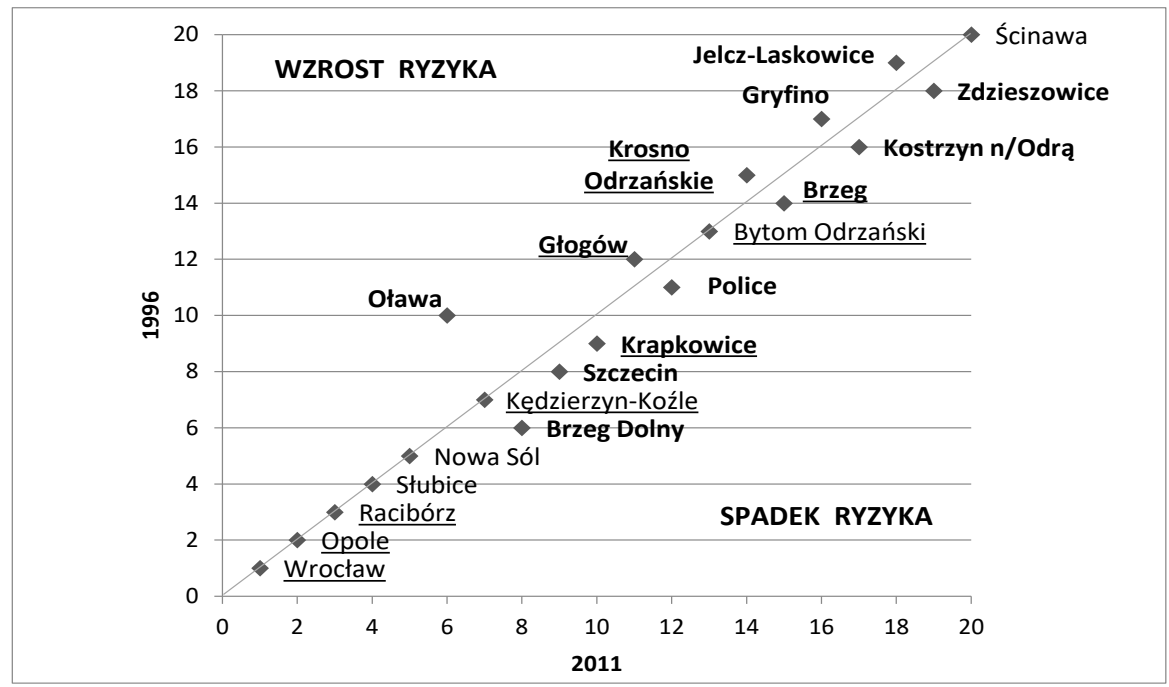

Podkreślenie - miasta dotknięte powodzią w $1997 \mathrm{r}$.

Wytłuszczenie - miasta, których pozycja w rankingu uległa zmianie.

Ryc. 9. Ranking miast według malejącego poziomu ryzyka powodziowego na obszarach potencjalnego zagrożenia powodzią w latach 1996-2011 - zmiany pozycji

Źródło: opracowanie własne

W przeciwieństwie do pierwszej strefy zalewowej, w drugiej strefie więcej zmian pozycji miast $\mathrm{w}$ rankingu według malejącego poziomu ryzyka nastąpiło w pierwszej części badanego okresu (w latach 1996-2004). Zmiany te dotyczą głównie spadku lokaty, świadczącego o obniżeniu poziomu ryzyka powodziowego w tych miastach względem pozostałych (tj. w Brzegu, Szczecinie, Kostrzynie nad Odrą, Brzegu Dolnym, Krapkowicach i Zdzieszowicach) (ryc. 10). W drugiej części analizowanego okresu (po 2004 r.) zmiany w rankingu miały mniej dynamiczny charakter (przed 2004 rokiem zmiany lokat miały rozpiętość od 1 do 3 pozycji, podczas gdy po 2004 roku maksymalnie o 1 pozycję) i dotyczyły w równym stopniu zarówno spadków (w Policach i Kędzierzynie-Koźlu), jak i wzrostów lokat w rankingu (w Głogowie i Oławie) (ryc. 10). 


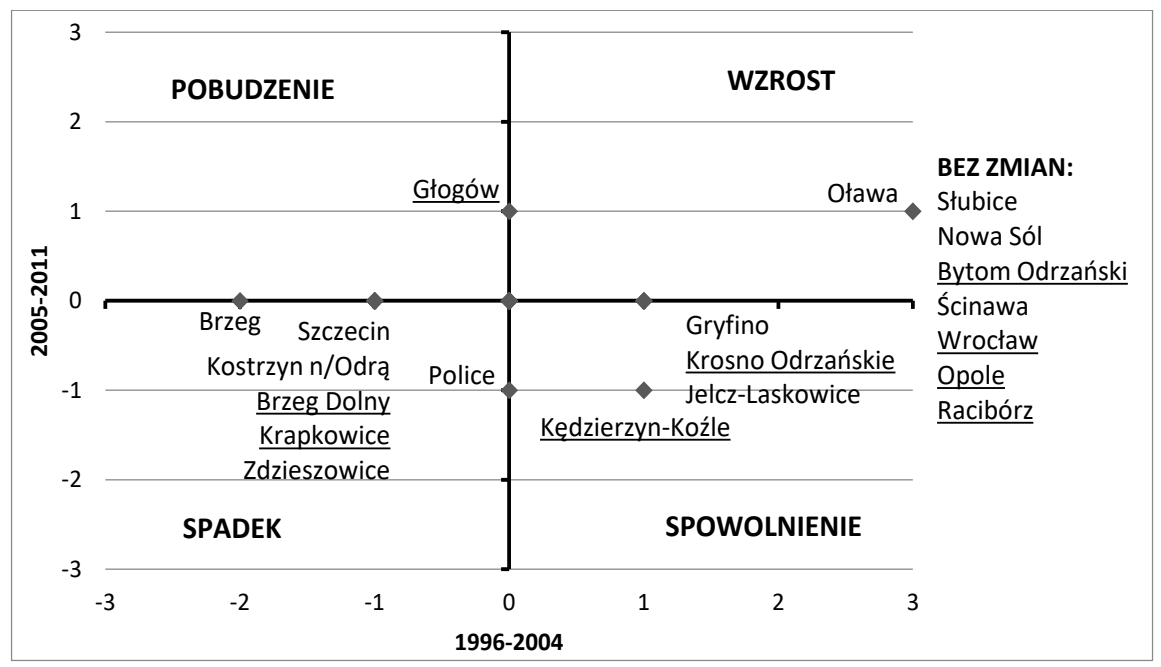

Podkreślenie - miasta dotknięte powodzią w $1997 \mathrm{r}$.

Ryc. 10. Zmiana pozycji w rankingu według malejącego poziomu ryzyka powodziowego na obszarach potencjalnego zagrożenia powodzią

w latach 1996-2004 i 2005-2011

\section{Źródło: opracowanie własne}

Przeprowadzone badania pozwoliły także ocenić zmiany ryzyka powodziowego miast nadodrzańskich, które dotknęła powódź tysiąclecia w 1997 roku, względem siebie. Są to miasta, które plasują się raczej w górnej i środkowej części listy rankingowej według malejących potencjalnych strat powodziowych i cechują się zróżnicowaną wielkością terenów zalewowych ogółem, jak i poszczególnych stref zalewowych oraz z reguły niskim poziomem zainwestowania terenów międzywala i wysokim - zawala (ryc. 2, 3, 4). W większości miast dotkniętych powodzią tysiąclecia (w 6 z 10 ośrodków, tj. we Wrocławiu, Opolu, Raciborzu, Kędzierzynie-Koźlu, Krośnie Odrzańskim, Bytomiu Odrzańskim) nie zaobserwowano w latach 1996-2011 zmian poziomu ryzyka powodziowego względem siebie w badanej grupie miast, a odnotowane zmiany dotyczą w równej mierze spadku i wzrostu potencjalnych strat powodziowych (po 2 miasta, tj. odpowiednio Brzegu Dolnego, Głogowa oraz Krapkowic i Oławy) (ryc. 5). Analizując poszczególne strefy zalewowe, aż w połowie miast zalanych w 1997 roku, na terenach międzywala zaobserwowano korzystne zjawisko spadku wysokości potencjalnych strat powodziowych względem innych miast ( $\mathrm{tj}$. we Wrocławiu, Brzegu, Krośnie Odrzańskim, Opolu i Głogowie), czego nie można zaobserwować na terenach chronionych wałami przeciwpowodziowymi, gdzie pod względem liczby ośrodków odnotowano w równej mierze spadek i wzrost ryzyka powodziowego w miastach dotkniętych powodzią tysiąclecia względem pozostałych ośrodków nadodrzańskich (po 2 miasta, tj. odpowiednio w Krapkowicach i Brzegu oraz w Głogowie i Krośnie Odrzańskim) (ryc. 7, 9). 


\section{Wnioski}

Określone w pracy ryzyko powodziowe odnosi się do całkowitych strat materialnych mogących powstać w wyniku powodzi, a zaobserwowane zmiany poziomu ryzyka powodziowego wynikają jedynie ze zmiany wysokości ewentualnych strat powodziowych w grupie badanych miast nadodrzańskich względem siebie.

Przeprowadzone badania wykazały, że o wysokości całkowitych potencjalnych strat powodziowych w miastach nadodrzańskich decyduje przede wszystkim wielkość terenów zagrożonych powodzią, a nie sposób ich zagospodarowania (zainwestowania). Analiza korelacji wykazała bowiem istotne statystycznie zależności między poziomem ryzyka powodziowego a powierzchnią terenów zalewowych (zarówno ogółem, jak i poszczególnych stref zalewowych). Najmniejszą korelację odnotowano na obszarach zalewowych ogółem, a największą w granicach drugiej strefy zalewowej. Zauważyć jednak można, że opracowany ranking miast według malejącego poziomu ryzyka powodziowego nie pokrywa się z listą rankingową prezentującą układ miast według powierzchni obszarów zalewowych.

Zaprezentowane wyniki badań wykazały dodatkowo, że w przypadku pierwszej strefy zalewowej, na poziom ryzyka powodziowego ma również wpływ stopień zainwestowania tych terenów (korelacja istotna statystycznie). Może to wynikać ze stosunkowo dużego zróżnicowania poziomu zainwestowania terenów międzywala $\mathrm{w}$ badanych miastach $\mathrm{w}$ porównaniu do terenów położonych za wałami przeciwpowodziowymi. Zatem w przypadku pierwszej strefy zalewowej, planowanie przestrzenne na tych terenach jest bardzo istotne $\mathrm{z}$ punktu widzenia kształtowania potencjalnych strat powodziowych w (zamkniętym) układzie badanych miast nadodrzańskich.

Otrzymane wyniki (w tym analizy korelacji) nie wskazują na zależność poziomu ryzyka powodziowego względem położenia miasta $\mathrm{w}$ określonym biegu rzeki. Nie można zatem stwierdzić, że wraz ze zmianą biegu rzeki zmienia się ryzyko powodziowe (potencjalne straty powodziowe) w miastach nadodrzańskich. W górnym biegu rzeki (tereny górzyste) wezbrania mają bardziej dynamiczny charakter i ryzyko wystąpienia powodzi jest większe z uwagi na duże spadki terenu, słabą przepuszczalność podłoża skalnego i silne opady atmosferyczne. Co za tym idzie, fala wezbraniowa na tym odcinku rzeki charakteryzuje się większą siłą niszczącą (Grocki 2003; Jermaczek i in. 2008). Zróżnicowane prawdopodobieństwo wystąpienia strat powodziowych względem biegu rzeki w badanych miastach odzwierciedla częstotliwość i wielkość powodzi historycznych. W ciągu ostatnich kilkudziesięciu lat, głównie miasta położone w górnym odcinku Odry, na obszarach górskich i podgórskich, były dotknięte klęską powodzi i poniosły $\mathrm{z}$ tego tytułu olbrzymie straty. 
Zaprezentowane wyniki badań pozwoliły wyszczególnić miasta wymagające szczególnej ochrony przed powodzią z uwagi na wysokie, całkowite straty mogące wystąpić na skutek powodzi. Należą do nich, oprócz Wrocławia, także Opole, Racibórz i Kędzierzyn-Koźle, czyli ośrodki położone w górnym odcinku rzeki Odry. Jest to bardzo niekorzystna sytuacja, ponieważ górny bieg Odry ma charakter górski, o czym już wspomniano w pracy, a co za tym idzie powodzie na tym odcinku są bardziej gwałtowne niż w niższym biegu rzeki, a mieszkańcy położonych nad nią miast mają mniej czasu na przygotowanie się do przyjęcia fali powodziowej.

Miasta nadodrzańskie w badanym okresie cechowały się niską zmiennością ryzyka powodziowego względem siebie w ujęciu dynamicznym. W 11 z 20 badanych ośrodków w latach 1996-2011 nie doszło do zmiany ryzyka powodziowego, biorąc pod uwagę obszary zalewowe ogółem. Niepokojącym zjawiskiem jest zachowanie wysokich pozycji przez miasta znajdujące się w czołówce rankingu według malejących, potencjalnych strat powodziowych. Oznacza to utrzymanie w nich wysokiego ryzyka powodziowego. Spadek ryzyka powodziowego względem innych miast odnotowano w nieco ponad połowie badanego zbioru. Zaobserwowane spadki potencjalnych strat powodziowych są jednak mniej dynamiczne niż wzrosty, co można ocenić negatywnie, ponieważ zaistniałe zmiany w zagospodarowaniu terenów zalewowych w większym stopniu generują wzrost niż spadek potencjalnych strat powodziowych w badanych miastach względem siebie. Ponadto z upływem czasu widać niekorzystne zjawisko zwiększenia liczby miast, w których doszło do wzrostu ryzyka powodziowego względem pozostałych miast na obszarach zalewowych ogółem. Jest to skutek rozwoju procesów urbanizacji na terenach zagrożonych powodzią. Intensyfikacja zagospodarowania terenów zalewowych powoduje bowiem wzrost wartości majątku zagrożonego powodzią i w przypadku wystąpienia powodzi wyższe straty ekonomiczne (Grocki, Eliasiewicz 2001; Radczuk, Żyszkowska 2001; Radczuk i in. 2001; Więzik 2010). Potwierdza to T. Jarzębińska (2006), według której coraz dynamiczniej na obszarach zalewowych rozwijają się tereny zurbanizowane. Mimo niebezpieczeństwa powodzi, wzrasta chęć lokalizacji zabudowy w bliskim sąsiedztwie rzeki (Plit 2008; Wheater, Evans 2009). Stosunkowo duża presja ekonomiczna i społeczna na rozwój zabudowy na obszarach zagrożonych powodzią, szczególnie na obrzeżach miast, wynika $\mathrm{z}$ niewystarczającej podaży terenów wolnych pod zabudowę w ośrodkach miejskich oraz środków finansowych na ich uzbrojenie, a także z reguły niższych cen gruntów położonych na obszarach zagrożonych (Warcholak, Kołodziejczyk 2007).

W pierwszej strefie zalewowej w badanych latach doszło do korzystnego spadku ryzyka powodziowego w większości miast o wysokich potencjalnych stratach powodziowych względem pozostałych ośrodków nadodrzańskich. Może być to wynikiem zmniejszenia intensywności zainwestowanych obszarów międzywala 
terenów zurbanizowanych, m.in. na skutek upadku zakładów produkcyjnych zlokalizowanych bezpośrednio nad rzeką (por. Jermaczek i in. 2008; Eckes 2010; Schneider-Skalska 2010). Zaobserwowano ponadto, że w strefie tej z upływem czasu nastąpił wzrost liczby miast, w których doszło do spadku ryzyka powodziowego względem pozostałych badanych miast, co również można ocenić pozytywnie.

Odnotowane zmiany w drugiej strefie zalewowej nie są z kolei już tak korzystne - w miastach o bardzo wysokich i wysokich potencjalnych stratach powodziowych, nie zaobserwowano zmian (spadku) ryzyka powodziowego względem pozostałych miast. Zmiany (zarówno spadki, jak i wzrosty) potencjalnych strat powodziowych w badanych ośrodkach względem siebie dotyczyły natomiast głównie miast o niskim ryzyku powodziowym. W drugiej strefie zalewowej odnotowano więcej zmian wysokości potencjalnych strat powodziowych miast względem siebie niż w pierwszej. Były one jednak mniej dynamiczne. Oznacza to $\mathrm{z}$ jednej strony liczne przekształcenia w zagospodarowaniu obszarów chronionych wałami przeciwpowodziowymi, $\mathrm{z}$ drugiej strony mniejsze ich znaczenie w generowaniu potencjalnych strat powodziowych w porównaniu do zmian zagospodarowania w granicach terenów międzywala.

Odnosząc się do zmian ryzyka powodziowego w miastach dotkniętych powodzią tysiąclecia w 1997 roku, jedynie w pierwszej strefie zalewowej można odnotować racjonalną reakcję ich mieszkańców na istniejące zagrożenie powodziowe, tj. w większości tych miast odnotowano zmiany zagospodarowania prowadzące do spadku potencjalnych strat powodziowych względem pozostałych ośrodków nadodrzańskich. Warto też zaznaczyć, że reakcja ta była opóźniona, ponieważ w przypadku miast dotkniętych powodzią w 1997 roku, spadek ryzyka powodziowego nastąpił głównie po 2004 roku, nie zaś od razu po wystąpieniu powodzi, tj. w latach 1996-2004. Z kolei na terenach potencjalnego zagrożenia powodzią zmiany dotyczyły w równej mierze spadku i wzrostu ryzyka powodziowego w stosunku do innych badanych ośrodków. Biorąc pod uwagę jednocześnie dwie strefy zalewowe (czyli tereny zalewowe ogółem), w analizowanych latach w większości miast nadodrzańskich dotkniętych powodzią w 1997 roku nie doszło jednak do zmian wysokości potencjalnych strat powodziowych względem pozostałych badanych ośrodków. Wyrządzone w 1997 roku przez powódź tysiąclecia olbrzymie straty nie wywołały zatem przekształceń w zagospodarowaniu terenów zagrożonych powodzią, skutkujących zmianą ryzyka powodziowego w tych ośrodkach względem pozostałych miast nadodrzańskich.

Warto zauważyć, że nie odnotowano prawidłowości odnośnie zmian ryzyka powodziowego względem siebie w miastach nadodrzańskich a ich położeniem w określonym biegu rzeki.

Zaprezentowane $\mathrm{w}$ pracy zmiany ryzyka powodziowego przedstawiają jedynie zmiany wysokości potencjalnych strat powodziowych miast nadodrzańskich względem siebie (zamknięty układ 20 ośrodków). Nie wyklucza to jednak 
ewentualnego ogólnego wzrostu ryzyka powodziowego w analizowanych miastach nadodrzańskich bądź też, mimo zaobserwowanego spadku potencjalnych strat powodziowych w jednym mieście względem drugiego, wzrostu ryzyka powodziowego w tym pierwszym. Wzrost potencjalnych strat powodziowych w pierwszym mieście mógł być mniejszy niż w drugim badanym ośrodku. Jest to wysoce prawdopodobne, ponieważ w badanych miastach w analizowanych latach (1996-2011) zaobserwowano ogólny rozwój zainwestowania na obszarach zagrożonych powodzią ogółem - wzrost udziału terenów zainwestowanych o 113\% w stosunku do roku bazowego - jak i w poszczególnych strefach zalewowych - w pierwszej wzrost o 108\%, w drugiej aż o 115\%. Ponadto jedynie w Policach odnotowano w latach 1996-2011 spadek zainwestowania na terenach zalewowych (wskaźnik dynamiki ok. 60\%). W pozostałych miastach nadodrzańskich doszło do rozwoju terenów zainwestowanych na obszarach zagrożonych powodzią. Największy przyrost zaobserwowano w Oławie, Jelczu-Laskowicach, Gryfinie, Brzegu Dolnym, Kostrzynie nad Odrą i Nowej Soli (wskaźnik dynamiki powyżej $140 \%$ ), najmniejszy zaś w Bytomiu Odrzańskim, Głogowie i Raciborzu (poniżej 110\%) (Lechowska 2016).

Przeprowadzone badania pokazują wzajemne relacje wysokości potencjalnych strat powodziowych we wszystkich miastach nadodrzańskich w Polsce oraz zmiany ich poziomu względem siebie w ujęciu czasowym. Obrazują one zatem rozkład przestrzenny ryzyka powodziowego na obszarach miejskich wzdłuż biegu rzeki Odry, który może być wykorzystany do racjonalnego planowania ochrony przeciwpowodziowej w dorzeczu tej rzeki.

\section{LITERATURA}

DUW, 2011, Program dla Odry 2006 - aktualizacja, Dolnośląski Urząd Wojewódzki - Pełnomocnik Rządu do Spraw Programu dla Odry 2006, Wrocław.

Eckes K., 2010, Analizy przestrzenne w czasie rzeczywistym dla wspomagania akcji ratowniczych na terenach dotkniętych powodzia, ,Roczniki Geomatyki”, 8(6): 63-68.

Feltynowski M., 2009, Ranking potencjału innowacyjnego polskich regionów z wykorzystaniem miar syntetycznych, [w:] Nowakowska A. (red.), Zdolności innowacyjne polskich regionów, Wydawnictwo Uniwersytetu Łódzkiego, Łódź: 25-40.

Feltynowski M., Nowakowska A., 2009, Metoda oceny potencjatu innowacyjnego regionów, [w:] Nowakowska A. (red.), Zdolności innowacyjne polskich regionów, Wydawnictwo Uniwersytetu Łódzkiego, Łódź: 11-23.

Grocki R., 2003, Vademecum zagrożeń, Dom Wydawniczy Bellona, Warszawa.

Grocki R., Eliasiewicz R., 2001, Zagospodarowanie terenów zalewowych, Biuro Koordynacji Projektu Banku Światowego, Seria: Ograniczanie Skutków Powodzi w Skali Lokalnej, Wydawnictwo Safage, Wrocław.

IKSR, 2001, Internationale Kommission zum Schutz des Rheins, Rheinatlas.

Jarzębińska T., 2006, Rola retencji w ochronie przeciwpowodziowej, [w:] Bednarczyk S., Jarzębińska T., Mackiewicz S., Wołoszyn E. (red.), Vademecum ochrony przeciwpowodziowej, Krajowy Zarząd Gospodarki Wodnej, Gdańsk: 101-123. 
Jermaczek A., Misztal K., Wasiak P., 2008, Przyczyny i skutki powodzi na Dolnym Ślasku - propozycje ekologicznych działań przeciwpowodziowych, Wydawnictwo Klubu Przyrodników w Świebodzinie, Gorzów Wlkp.

Kitowski K., 2010, Dyrektywa powodziowa a prewencyjne planowanie przestrzenne, „Przegląd Komunalny”, 7 (226): 48-51.

Klepacz J., Łagosz R., 2008, Zbiornik Racibórz w układzie komunikacyjnym drogi wodnej Odra-Dunaj, [w:] Nycz E., Pistelok F. (red.), Odra. Rzeka i ludzie - wzajemne uwarunkowania na przestrzeni dziejów, Państwowa Akademia Nauk, Instytut Śląski, Opole-Katowice: 111-124.

Lechowska E., 2016, Zmiany zagospodarowania obszarów zalewowych i ich wplyw na poziom ryzyka powodziowego $w$ miastach nadodrzańskich $w$ Polsce, Wydawnictwo Naukowe Bogucki, Poznań.

NIK, 2011, Najwyższa Izba Kontroli. Informacja o wynikach kontroli realizacji programu wieloletniego ,Program dla Odry 2006”, Wrocław (Nr ewid.: 145/2011/P10/180/LWR).

Plit J., 2008, Zarzadzanie krajobrazem dolin rzecznych, „Prace Komisji Krajobrazu Kulturowego", 10: 230-240.

Radczuk L., Szymkiewicz R., Jełowicki J., Żyszkowska W., Burn J.F., 2001, Wyznaczanie stref zagrożenia powodziowego, Seria: Ograniczanie skutków powodzi w skali lokal$n e j$, Biuro Koordynacji Projektu Banku Światowego, Wydawnictwo Safege, Wrocław.

Radczuk L., Żyszkowska W., 2001, Sposoby wykorzystania stref zagrożenia powodziowego, Biuro Koordynacji Projektu Banku Światowego, Seria: Ograniczanie skutków powodzi w skali lokalnej, Wydawnictwo Safege, Wrocław.

Rozporzadzenie Ministra Środowiska, Transportu, Budownictwa i Gospodarki Morskiej, Administracji i Cyfryzacji oraz Spraw Wewnętrznych z dnia 21 grudnia 2012 roku w sprawie opracowania map zagrożenia powodziowego oraz map ryzyka powodziowego (Dz. U., 2013, poz. 104).

Schneider-Skalska G., 2010, Projektowanie zrównoważone terenów nadrzecznych miast, [w:] Więzik K. (red.), Prawne, administracyjne i środowiskowe uwarunkowania zagospodarowania dolin rzecznych, Wydawnictwo Wyższej Szkoły Administracji, Bielsko-Biała.

Słota H., 2000, Risk in flood control, The Monograph of the Water Management Committee PAN.

Starzyk E., Walczykiewicz T., 2000, Hierarchizacja miast województwa małopolskiego $w$ aspekcie potencjalnych strat $i$ zagrożenia powodziowego - Model kompleksowej ochrony przed powodzia na przykładzie województwa małopolskiego - zad. 5.1. w ramach Projektu badawczego zamawianego Wojewody Małopolskiego Nr PBZ -006-14.

Śliżewski B., 2008, Ocena ryzyka powodziowego w Niemczech w świetle Dyrektywy Powodziowej, „Gospodarka Wodna”, 9: 362-365.

Twaróg B., 1997, Optymalna ochrona przed powodziami z uwzględnieniem ryzyka, Grant $-5 \mathrm{P} 06 \mathrm{H} 03814$.

Twaróg B., 2002, Optymalna ochrona przed powodziami z uwzględnieniem ryzyka, Wydział Inżynierii Środowiska, Politechnika Krakowska.

Twaróg B., 2004, Optimal flood protection with risk consideration. Ochrona i Inżynieria Środowiska Zrównoważony Rozwój, ,Monografie Komitetu Inżynierii Środowiska PAN”, 25.

Warcholak P., Kołodziejczyk U., 2007, Stubice - potencjalny lubuski Nowy Orlean, „Gospodarka Wodna”, 10: 419-425. 
WBU, 2002, Wojewódzkie Biuro Urbanistyczne. Studium zagospodarowania przestrzennego pasma Odry - Synteza, Wrocław.

Wheater H., Evans E., 2009, Land use, water management and future flood risk, „Land Use Policy", 26(1): 251-264.

Więzik B., 2010, Wpływ zagospodarowania międzywala na zagrożenia powodziowe, [w:] Więzik K. (red.), Prawne, administracyjne i środowiskowe uwarunkowania zagospodarowania dolin rzecznych, Wydawnictwo Wyższej szkoły Administracji, Bielsko-Biała.

\title{
FLOOD RISK IN THE ODRA CITIES IN THE CONTEXT OF THE FLOODPLAINS MANAGEMENT
}

\begin{abstract}
This paper is aimed to determine the flood risk level based on the land use patterns - in towns located on the Odra river in Poland. The flood risk is determined by the area of particular forms of land use within the floodplain boundary. The assessment was made by linear ordering and grouping of all Odra cities by flood risk level (city ranking). The results obtained show the flood risk level of cities relative to each other. The time range adopted for research allows for a comparative analysis of the examined cities in terms of potential flood losses both statistically and dynamically. Particular attention was paid to the identification of relationships between the level of flood risk and the area of floodplains, and the way of its management expressed by the degree of investment and the location of the city in the course of the river.

The research shows that the total magnitude of potential flood losses is primarily determined by the size of the areas at risk of flooding and, to a lesser extent by their management (investment). Only in the case of the first flood zone (direct flood hazard zone), the impact of floodplain management on the level of flood risk was observed. However, there isno correlation between the level of flood risk and the location of the city in the river course. The work also focused on the analysis of flood risk changes in Odra cities relative to each other, including those affected by floods in 1997.
\end{abstract}

Keywords Flood risk, land use, floodplains, Odra river.

Dr Ewa Lechowska

Zakład Planowania Przestrzennego Instytut Geografii Społeczno-Ekonomicznej i Gospodarki Przestrzennej Wydział Nauk Geograficznych i Geologicznych Uniwersytet im. A. Mickiewicza w Poznaniu e-mail: ewaglo@amu.edu.pl 